\title{
Development of Website-Based Learning Media Integrated Inquiri Learning Strategies in Learning Thermochemical Matter Chemistry
}

\author{
Bambang Enra Priando Purba ${ }^{1}$, Ida Duma Riris ${ }^{2}$, Zainuddin Muchtar $^{3}$ \\ ${ }^{1,2,3}$ Universitas Negeri Medan, Indonesia \\ bambang.eppurba@gmail.com
}

\begin{abstract}
This research is a research on the development of Website learning media. This study aims to produce a product in the form of website learning media on thermochemical material that has been developed and its effect on student learning outcomes. This research was conducted by analyzing several Thermochemical learning websites with good ratings by 15 teachers who teach Chemistry in Serdang Bedagai Regency. From this analysis, it was obtained that the average count for Website A was 3.64 and Website B was 3.83, with sufficiently valid information but still requiring improvement in its presentation. The results of the analysis become a reference point in developing the Website learning media. The website that has been developed is analyzed according to the BSNP standard by 2 IT learning experts with an average result of 4.76 with very valid criteria. In addition, 15 teachers obtained an average score of 4.74 with very valid criteria. Limited trials of student learning outcomes were analyzed using independent $t$-test, with a value of $t$-count $>t$-table (3.89> 1.70), which means that with the implementation of integrated website media the inquiry learning strategy is higher than the KKM of the school at the level of significance of 0.05 .
\end{abstract}

Keywords inquiry; website; thermochemistry

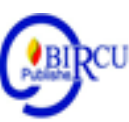

\section{Introduction}

Active student learning followed by the use of Informatics Engineering and scientific practice has become a pedagogical approach to learning (Sun \& Looi, 2013). Learning that is supported by the presence of technology has been developed, tested, analyzed and evaluated. Instructions such as WISE, Co-Lab, nQuire, Inquiry Island, and ModelingSpace are examples of learning that utilize internet technology in the learning process (White \& Frederiksen 1998).

There are several technologies that can be used in the learning process, one of which is Website Technology. The use of Website technology in learning can stimulate student motivation. This can be seen in Buchanan's research which conducted an online questionnaire about the use of technology in learning at a university. It is stated that student learning motivation is directly proportional to the use of technology provided by the university (Buchanan et al, 2013). This indicates that there are key variables that affect a person's motivation to utilize technology. The key variables are perceived usefulness and perceived ease of use (Buchanan et al., 2013). Freasier research who assigns assignments through the Website, stated that $94 \%$ of students felt very helpful in understanding their chemistry. The website contains content on the discussion of chemistry problems, along with the exercises. This increases students' interest in learning Chemistry (Freasier et al., 
2003). Technology and education cannot be separated, all of which must be in line. Learning activities must use blended learning because e-learning is one way for lecturers and students to use technology (Syakur et al in K. Hamid, 2020).

Hartshorne and Ajjan who gave questionnaires to students in the Southeastern United States about the use of WEB 2.0 in learning. The results show that students are very happy to use learning website, because the website helps them in mastering a learning material in a fun way. Not only that, they can also discuss with other friends using the Chat facility so that they can discuss even though they are not in the same place (Hartshorne \& ajjan, 2009). For students who are classified as weak in classroom learning, this website learning is one solution so that these students can improve the quality and quantity of their learning both inside and outside school learning (Jaaman et al. ,2013; Sudha \& Amuta, 2015; Sujanem, 2012). This is in line with the results of Jaamaan's research which stated that sStudents who are taught using Website-based learning have better learning outcomes, especially for students who are classified as weak in class learning. (Jaaman et al., 2013). Acquiring information is very fast on current technology, making students have to be able to use technology in their formal and social education (Yesiltas, 2016). There are many advantages that will be obtained with this website-based learning, such as context-free, free of social conventions, not too time-bound and able to adapt to individual student abilities (Candiasa, 2004). To do this, the learning strategy used must also be appropriate. Good learning is learning that offers a variety of ways of learning (Angell et al., 2004).

CEC Teacher Resources stated that several teachers and institutions provide access to Web-based teaching materials through links on Web pages. An example is how Columbia Education Center provides access to supplemental Web-based Teaching Materials.University professors and departments often provide similar resource pages to augment learning opportunities for their students. These resources are especially helpful when they provide an extension beyond what is covered in the classroom (i.e. materials on specific disciplines for Education majors who may be have deep knowledge in a specific discipline). Several companies and cooperative efforts have emerged to provide online access to Web-based teaching materials. These entities range from companies producing their own edutainment media to sites provided to aggregate links to other existing content. While the missions of these organizations may differ, they all focus on furthering the World Wide Web as the delivery medium for teaching materials. Web-based teaching materials emerged as elements on personal Web sites with the proliferation and adoption of the Internet in the early to mid-90s. Beyond personal publishing, Web-based teaching materials were often published online as samples and supplemental materials by commercial entities experimenting with the World Wide Web. Sites devoted to specific topics began aggregating links to these resources in efforts to capture educator audiences in the late 90s. These concepts were then extended to the Learning Management System (LMS) and Learning Content Management System (LCMS) as a way for instructors to organize and provide access to learning materials already available online. These systems also contain authoring tools that allow pieces of entire courses (including Web-based teaching materials) to be published online.

Web based learning is often called online learning or elearning because it includes online course content. Discussion forums via email, videoconferencing, and live lectures (video streaming) are all possible through the web. Web based courses may also provide static pages such as printed course materials. One of the values of using the web to access course materials is that web pages may contain hyperlinks to other parts of the web, thus enabling access to a vast amount of web based information. 
Several approaches can be used to develop and deliver web based learning. These can be viewed as a continuum. At one end is "pure" distance learning (in which course material, assessment, and support is all delivered online, with no face to face contact between students and teachers). At the other end is an organizational intranet, which replicates printed course materials online to support what is essentially a traditional face to face course. However, websites that are just repositories of knowledge, without links to learning, communication, and assessment activities, are not learner centered and cannot be considered true web based learning courses. Web based learning in an institution is often integrated with conventional, face to face teaching. This is normally done via an intranet, which is usually "password protected" and accessible only to registered users. Thus it is possible to protect the intellectual property of online material and to support confidential exchange of communication between students. As students are usually in large groups for basic science teaching, web based learning can be used to provide learning materials to complement conventional programmes and to enable self assessment-for example, access to anatomical sites and image banks for the teaching of pathology courses. Web based learning can be useful to support clinical teaching when learners are geographically dispersed.

Inquiri learning strategies can help student development such as scientific literacy and understanding of scientific processes, vocabulary knowledge and understanding of concepts, critical thinking, and being positive. By implementing the inquiry learning strategy students will be motivated to learn (Pea, 2012).Inquiry learning is very relied on to improve learning outcomes and student learning activeness. After students carry out inquiry learning, students become motivated to learn SAINS, and improve student learning outcomes (Wang et al, 2015). Learning using the inquiry learning strategy helps students to carry out a scientific investigation, so that students have a level of critical thinking about something (Abir \& Dori, 2013). Sipayung (2020) stated that teachers must strive to improve the ability to apply ICT in learning. This can bring an increase in student motivation. Realizing that through the internet can be found various information that can be accessed easily, anytime and anywhere, then the use of the internet becomes a necessity. Not only that, internet users can communicate with other parties in a very easy way through emoderating techniques available on the internet (Indrakasih, 2019).

\section{Research Methods}

This research is a development research. Where the research aims to produce a product in the form of a website learning media on Thermochemical material that has been developed and its effect on student learning outcomes. While the design of this study used the One Group Pretest-Postest Design. In this study, there was one class selected randomly, then given a pretest to determine the initial state of the class. In this study, the pretest and posttest scores were obtained from the results of the students' initial and final tests on Thermochemistry material. This is intended so that researchers know the state of student learning outcomes before and after the treatment is given. The experimental design in the study is shown in the table below:

Table 1. Experimental Research Design

\begin{tabular}{lccc}
\hline \multicolumn{1}{c}{ Group } & Pretest & $\begin{array}{c}\text { Treatment } \\
(\mathbf{X})\end{array}$ & Postest \\
\hline $\begin{array}{l}\text { Experiment } \\
\text { Class }\end{array}$ & $\mathrm{O} 1$ & $\mathrm{X}$ & $\mathrm{O} 2$ \\
\hline
\end{tabular}


All instruments used, both test and non-test, are instruments whose validity has been measured. So that all test and non-test instruments are suitable for use as research instruments in this study.

\section{Results and Discussion}

The results of the study are descriptions of the data obtained after conducting the research. The data described in this study include:

\subsection{Results}

\section{a. Analysis of Existing Websites}

Before analyzing the media that has been developed, the researcher analyzes the existing Thermochemical learning website. The basis for choosing this website is the Thermochemistry learning website which has a good rating. The results of the analysis of existing Thermochemical learning websites based on display aspects, programming aspects and media completeness aspects can be seen in the following graph.

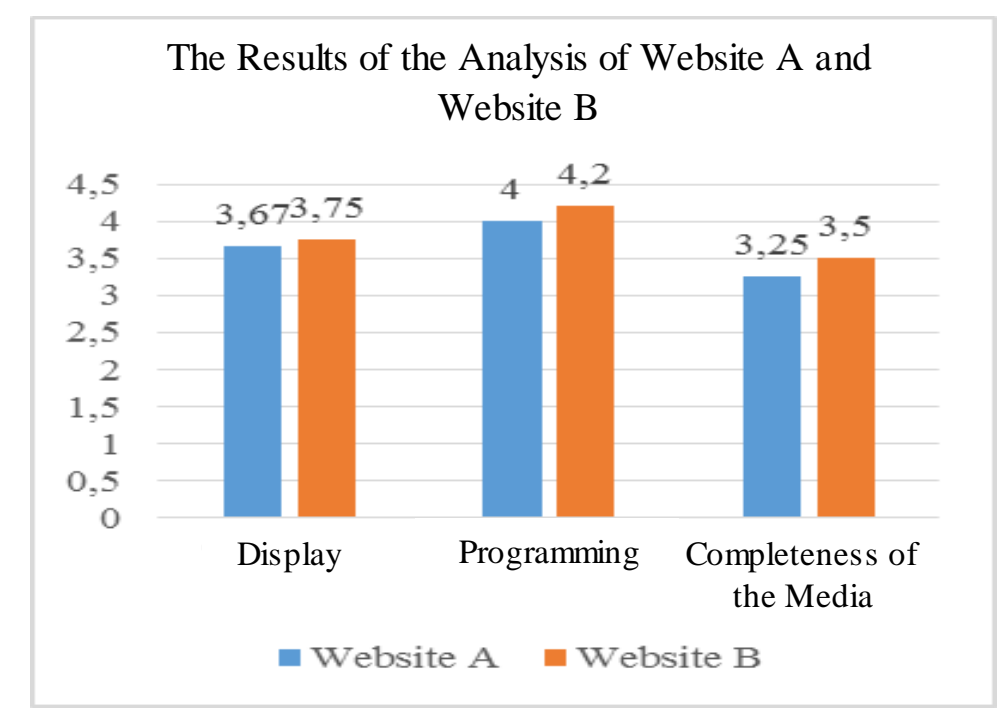

Figure 1. Results of the Analysis of Website A and Website B

The results of the analysis of the Thermochemistry learning website A obtained an average value of 3.64 or in other words, it is valid and does not require improvement when used in Thermochemistry learning. The description of each aspect has an average value, namely: 1) Display Aspect 3.67 (Valid), 2) Programming Aspect 4 (valid) and media completeness aspect 3.25 (Quite valid). The results of the analysis of the Thermochemistry learning website B obtained an average value of 3.83 or in other words, it is valid and does not require improvement if it is used in Thermochemistry learning. The description of each aspect has an average value, namely: 1) Display Aspect 3.75 (Valid), 2) Programming Aspect 4.25 (valid) and media completeness aspect 3.5 (valid).

\section{b. Validation Analysis of Innovative Website Learning Media}

Website-based learning media that have been developed are then standardized or validated using a website-based learning media assessment questionnaire that has been modified according to the needs of website-based learning media assessments from the National Education Standards Agency (BSNP) eligibility questionnaire by 2 website media (IT) experts. The results of validation by media experts can be seen in the following graph. 


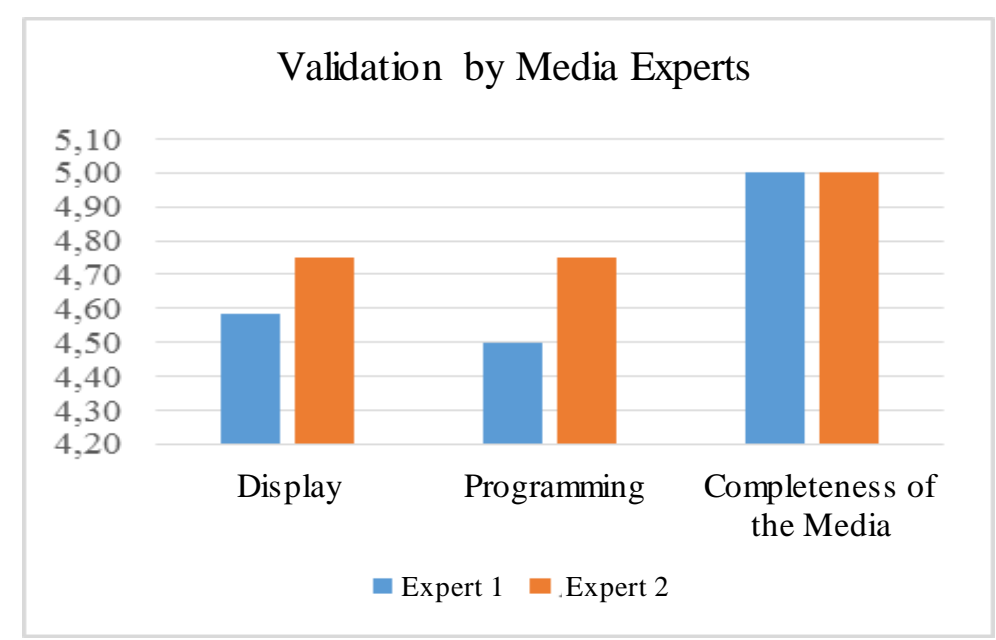

Figure 2. Results of Validation by Media Experts

Based on the validation results of the feasibility test for integrated website-based learning media. Inquiry learning strategy by 2 Website media experts can be seen the validation range for each aspect of the feasibility of the assessment according to the BSNP questionnaire. For the feasibility of the Display aspect, the average value obtained is 4.67. For the feasibility of the programming aspect, an average of 4.63 was obtained, and for the feasibility of the Media Completeness aspect, an average of 5.0 was obtained. Respondents in this case also added some input or suggestions such as improving the appearance of the template, adding links and making the same background on each website display (in this case a different view is the CBT facility on Website-based learning media).

\section{c. Analysis of Research Data}

The results of the limited trial of student learning outcomes indicate that there is a significant difference in the data acquisition of students' pretest and posttest scores, as shown in the figure below.

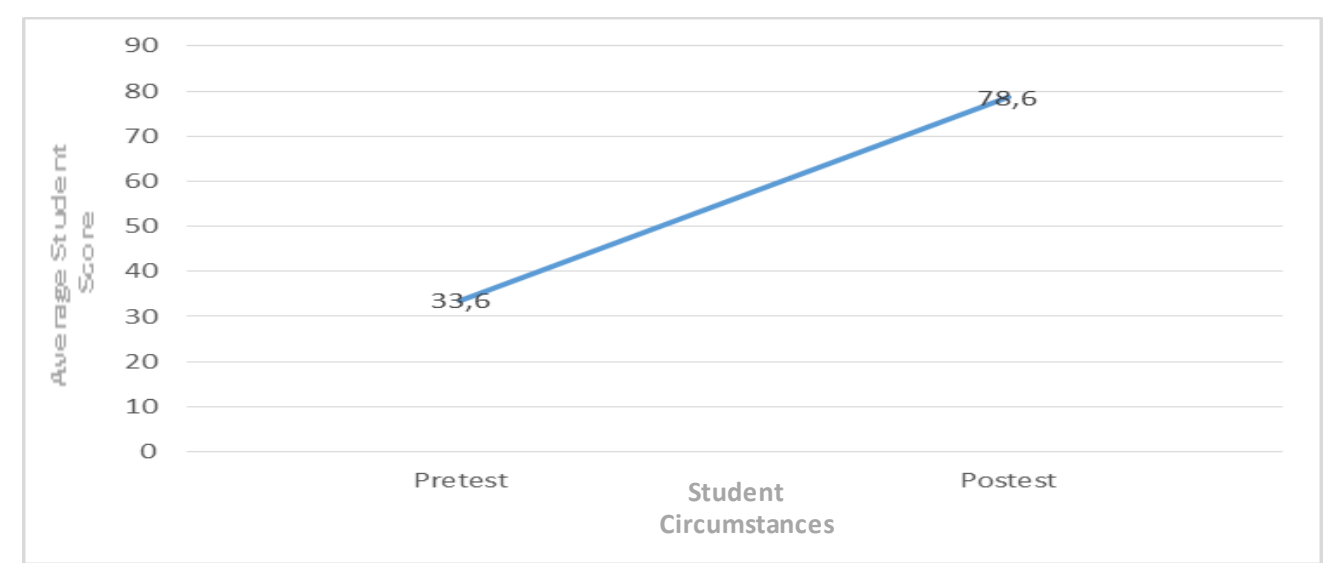

Figure 3. Distribution of Experimental Class Pretest and Posttest Acquisition

Overall, the average pretest value of the experimental class was 33.60 and the average posttest price was 78.60. The increase in learning outcomes for the experimental class was 0.68 or $68.35 \%$ so that it met the moderate criteria, where the gain value was $<0.7$.

Based on the data on student learning outcomes and the results of the calculation of the results of the hypothesis test of learning outcomes can be seen in the table below. 
Table 2. Learning Outcomes Hypothesis Test Results

\begin{tabular}{cccc}
\hline $\begin{array}{c}\text { Data } \\
\text { Source }\end{array}$ & Class & t count & t table \\
\hline $\begin{array}{c}\text { Learning } \\
\text { Outcomes }\end{array}$ & Experiment & 3.89 & 1,708 \\
\hline
\end{tabular}

Based on the results of hypothesis testing student learning outcomes, the price of tcount $>$ ttable is 3.89> 1.708 with a significance level $(\alpha=0.05)$ so that it can be concluded that the thermochemical learning outcomes of students with the implementation of the integrated website media inquiry learning strategy are higher than the school KKM. Where, the KKM value in this research is 70 .

\subsection{Discussion}

Developing students' mathematical power is an integral part of developing a teacher's professional competence. Mathematical power affects how individuals process and learning outcomes to acquire knowledge, skills and attitudes which will be reflected in daily behavior and serve to motivate, stimulate appreciation of the complexity of student success in interdisciplinary learning. Teachers should design and develop learning tools and carry out mathematics learning to develop students' mathematical power through the application of innovative and creative scientific learning as well as assess integrated mathematical power in problem solving abilities. Guided Discovery Learning has made students more independent and active in thinking in their learning, but some students are still not able to understand the concepts to solve problems and have not fully mastered problem solving skills. In solving problems, some students make mistakes in solving mathematical problems because of their lack of understanding in interpreting information about problems in the form of mathematical operations. Conceptual difficulties, namely difficulties in applying concepts to solve problems, and procedural difficulties, namely difficulty in presenting the steps in solving problems, as well as difficulties in developing problem solving strategies effectively and efficiently still occur in students. The assessment of mathematical power must cover all aspects identified in this mathematical power standard and be integrated into its mathematical ability. Assessment of the strength of mathematics is an assessment of competency assessments that is not separated from one another, but the emphasis must remain clear that the strength of mathematics concerns all aspects of mathematical knowledge and its integration (Kusmaryono, 2014).

\section{Conclusion}

Based on the results of data analysis, findings and discussion of this study, it can be concluded that the website media that has been developed is suitable for use in high school chemistry learning. This is evidenced by the feasibility test of the media which gets an average score of 4.75 by a team of experts and teachers with very valid criteria and does not require improvement. Learning media that have been developed are very suitable for the learning situation at this time and in the future. Where, technology is increasingly advanced and technology-based learning must also be developed. Thermochemistry learning outcomes of students with the implementation of the integrated website media inquiry learning strategy were higher than the school KKM. This is proven by testing the hypothesis where t count (3.89)> $t$ table (1.70). 


\section{Thank-you Note}

The researcher thanked God Almighty for providing the opportunity to finish what the researcher had started. The researcher also expressed his gratitude to the research supervisor who did not get bored of supporting and guiding the researcher so that he could complete this research. Thank you also for the support of your wife and family who are always there so that researchers can complete this research.

\section{References}

Abir, A., Dori, YJ (2013). Inquiry, Chemistry Understanding Levels, and Bilingual Learning, educación química, 24, 37-43

Angell, C., Guttersrud, Ø, Henriksen, EK, \& Isnes, A. (2004). Physics: Frightful, but fun. Pupils 'and teachers' views of physics and physics teaching. Science Education, 88, 683-706

Buchanan, T., Sainter, P., Saunders, G. (2013). Factors affecting faculty use of learning technologies, implications for models of technology adoption, 25 (1), $1-11$

Candiasa, IM, (2004), Learning with WEB-Based Modules, Journal of Education and Teaching Singaraja, 37, 1-9

Freasier, B .; Collins, G .; Newitt, P. (2003) .A Web-Based Interactive Homework Quiz and Tutorial Package Tu Motivate Undergraduate Chemistry Student and Improve Learning. Journal Of Chemical Education, 80 (2): 1344 - 1347

Hartshorne, R., Ajjan, H. (2009) Examining student decisions to adopt Web 2.0 technologies: theory and empirical tests. J Comput High Educ, 21 (2): 183-198

Indrakasih, et al. (2019). Development of Basic Volleyball Learning Media Based on Web Learning Materials Towards KKNI at Universitas Negeri Medan. Budapest International Research and Critics in Linguistics and Education (BirLE)Journal Vol 2 (4): 139-144.

Jaaman, SH, Ahmad, RR, Rambely, AS (2013). Web-Based Learning as a Tool of Knowledge Continuity, 6 (1), 80 - 85

Pea, CH (2012) Inquiry-based Instruction: Does School Environmental Context Matter. Science Educator, 21 (1), 37-43

Sipayung, T.N., et al. (2020). An Analysis of Students Motivation in Online Learning Based on Realistic Mathematical Comic Videos. Budapest International Research and Critics Institute-Journal (BIRCI-Journal) Vol 3 (4): 3861-3871.

Sudha, A., Amutha, S. (2015). Higher Secondary Learners' Effectiveness towards Web Based Instruction (WBI) on Chemistry. Universal Journal of Educational Research, 3, 463-466

Sujanem, R ; Suwindra, INP; Tika, IK (2009). Development of WEB-Based Interactive Contextual Physics Module for Class I High School Students. Journal of Education and Teaching, 42, 97-104

Sun, D., Looi, CK (2013). Designing a Web-Based Science Learning Environment for Model-Based Collaborative Inquiry. J Sci Educ Technol, 22 (1), 73-89

Syakur, A., et al. (2020). The Effectiveness of English Learning Media throughGoogle Classroom inHigher Education. Britain International of Linguistics, Arts and Education (BIoLAE) Journal, 475-483.

Wang, P,. Wu, P., Yu, K., Lin, Y. (2015). Influence of implementing inquiry-based instruction on science learning motivation and interest: a perspective of comparison. Procedia - Social and Behavioral Sciences, 174, 1292 - 1299 
White BY, Frederiksen JR. (1998). Inquiry, modeling, and metacognition: making science accessible to all students. Cogn Instr, 16 (1), 3-118

Yesiltas, E. (2016) An Analysis of Social Studies Teachers' Perception Levels Regarding Web Pedagogical Content Knowledge. 9, 108 - 123. 